\title{
Halal Tourism Destination in UAE: The Opportunities, Threats and Future Research
}

\author{
Abdulla Al-hammadi, Samer Ali Al-shami, Abdulhadi Al-Hammadi, Nuruliza Rashid
}

\begin{abstract}
This paper aims to discuss the opportunities of Halal tourism destination in the UAE and challenges that impede this industry. It also intends to propose the future research to advance this industry. Halal tourism Has globally become attractive industry due to the demand growth not only from Muslims tourists, non-Muslims as well. Thus, many Muslims and non-Muslims countries have taken an initiative to innovative and diversify their tourism industry through developing Halal tourism that attract tourists' satisfaction and loyalty. The UAE as a leading and innovative country has taken initiative to support this industry and transform UAE to become the first leading Halal tourism in the world. However, the portfolio of tourism industry and its contribution to GDP still very low fills in $12 \%$ only. This put a pressure to the country in how to innovate and diversify the tourism industry in general and Halal tourism to become the most attractive world tourism destination. We found that, as the key driver of this industry is the tourists' perspective about the motivation factors and since the customersbehaviour is always changing, we argue that understand the motivation factors from tourists' perspective towards Halal tourism destination is the key driver to develop world Halal tourism destination.
\end{abstract}

Keyword-Halal, Tourism, Opportunities, Threats, Future, Research

\section{INTRODUCTION}

Tourism is in essence a series of flows and movements. Tourism is not just an industry, but a complex system with many interrelated components and involves various stakeholders (Mai and Bosch, 2010). Travelling outside the borders of one's own country has been restricted and limited in the early years of the Roman Empire (Holloway and Humphreys, 2017). It was only in the late eighteenth century that passports were issued and international travel monitored (Holloway and Humphreys, 2017). Since then tourism has grown at a rapid rate, and in 2016 tourism was directly responsible for GDP grew by $3.1 \%$ (Holloway and Humphreys, 2017). This was faster than the global economy as a whole which grew at $2.5 \%$. The direct contribution of Travel \& Tourism to employment grew by $1.8 \%$ in 2016 meaning almost 2 million net additional jobs were generated directly by the sector, and a total of around 6 million new jobs created as a result of total direct, indirect and induced activity (Holloway and Humphreys, 2017). In 2020, the international arrives are expected to reach1.6 billion. Of these worldwide arrivals in 2020, 1.2 billion will be intraregional and 378 million will be long-haul travellers

Revised Manuscript Received on April 12, 2019.

Abdulla Al-hammadi,UniversitiTeknikal Malaysia MelakaInstitute of Technology Management and Entrepreneurship. (E-mail: a41151@hotmail.com)

Samer Ali Al-shami, UniversitiTeknikal Malaysia MelakaInstitute of Technology Management and Entrepreneurship.

Abdulhadi Al-Hammadi, UniversitiTeknikal Malaysia MelakaInstitute of Technology Management and Entrepreneurship.

Nuruliza Rashid, UniversitiTeknikal Malaysia MelakaInstitute of Technology Management and Entrepreneurship.
(Association of Bhutanese Tour Operators, 2018). According to (Dwyer et al., 2009), the most important aspect of tourism management is to understand the key drivers of tourism and how they impact on tourism. One of these key drivers is the conventional way of addressing tourist behaviour and motivation (Cohen, Prayag and Moital, 2014). If planning of tourism is executed effectively and all the drivers thereof are considered, it will generate revenue and employment (Grissemann and StokburgerSauer, 2012; Garsous et al., 2017) which contribute to poverty reduction (Scheyvens and Russell, 2012).

The way in which tourist behaviour, addressed and motivated, are becoming seriously outdated.It is suggested that it in the eighties that over time the needs and motivators of tourists had changed. The "New Tourist" is emerging and (Lubbe, 2005) mentioned that tourists are becoming more discerning and demanding, more interested in an individual experience and special interest travel, looking for interactivity and they are more educated and want to enrich their lives and knowledge. Thus, they travel longer distances and spend more money (Qian, Law and Wei, 2018). Understanding why people travel and take holiday trips, how they go about selecting their destinations and why one country is preferred above the other are vital to those who are interested in tourism (Holloway and Humphreys, 2017), and the motivation (needs) for travel is one of the most important factors that need to be considered when designing tourist packages (Getz and Brown, 2006). Thus, why people travel and where they travel(Khuong and Ha, 2014) to should be the main focus of any business dealing with the selling of or offering of holiday packages (Perks and Ferreira, 2017). Furthermore, the destination attributes and accessibility of destinations also need consideration, as these influence the image that the tourist has of the destination (Seyidov and Adomaitiene, 2016). All people differ; due to this, people will have different motivations to visit a certain destination and for choosing specific destinations (Jönsson \& Devonish 2008.398).However, past research paid attention to the general and mutual pull and push motivation factors that influence tourists behaviour to visit a certain destination without giving a considerable attention to other factors such as religion, culture and customs which influence the decision of tourists (El-gohary, 2016).

This leaves a big challenge to tourism agencies as well as countries in how to satisfy those who are influenced by their culture, religion and lifestyle. For example, Muslims form about $24.1 \%$ of the world population (Waldman and Zeghal, 2009), and their travel contributed over US\$156 billion to

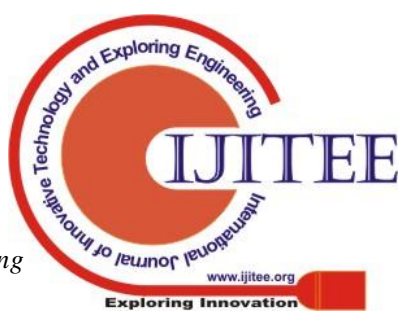


global GDP in 2016 and is primed to grow to US\$220 billion by 2020 according to the Global Muslim Travel Index 2017 and their behaviour towards tourism destination is influenced by their religion and culture that complies with Sharia law or so called Halal (Waldman and Zeghal, 2009). While a few empirical studies have been conducted on the halal tourism sector (Shafaei and Mohamed, 2015; Battour and Ismail, 2016; Razzaq, Hall and Prayag, 2016), ,understanding of the interests, motives and requirements of tourists at these is yet limited (El-gohary, 2016) factors that influence the satisfaction of tourists or their loyalty still not well documented (Wardi, Abror and Trinanda, 2018), especially with the current debated about the concept of halal tourism (El-gohary, 2016).In addition, there is no study explored the motivation factors of Halal tourism destination from the perspective of UAE even though, it is one of the leading countries worldwide in tourism industry generally and Halal tourism particularly.Therefore, this research aims to identify the motivation factors towards Halal tourism destination from the UAE perspective and explain how they influence tourists' loyalty.

Nowadays, Halal tourism has become a global brand and many of non-Muslims consume Halal products. For example, (e.g., Japan and South Korea) have been adopting halal tourism by offering and delivering Muslim-friendly tourism products and services (Han et al., 2019).According to the Global Muslim Travel Index (GMTI) (2018) report, the top ten Muslim-friendly destinations among non-Islamic nations are Singapore, South Africa, Thailand, United Kingdom, Bosnia and Herzegovina, India, Germany, Australia, and Tanzania. However, the past studies have not paid enough attention to how do the motivation factors of Halal tourism influence non-Muslims tourists satisfaction and behaviour towards Halal tourism product generally and to the best of the research, no study has been conducted in the UAE. This leaves a gap in how to develop international Halal tourism brand, especially in the UAE where the majority of the tourists are worldwide and non-Muslims as well. Therefore, this research aims to investigate how motivation factors of Halal tourism influence both Muslims and non- tourists' loyalty and behaviour.

\section{TOURISM INDUSTRY IN THE UNITED ARAB OF EMIRATE}

The united Arab Emirate is one of the Middle East countries located in the Western Asia in the Southeast end of the Arabian Peninsula on the Persian Gulf and bordering Oman in the east and Saudi Arabia in the south. UAE also sharing the maritime borders with Qatar in the west and Iran in the North. The UAE was established on 2 December 1971 and consist of seven emirates namely Abu Dhabi, Ajman, Dubai, Fujairah, Ras Al-Khaimah, Sharjah and Umm AlQuwain. UAE recognized Islam as the main religion and this country role by the president of the United Arab Emirates selected from the Emirates. The UAE population was 9.2 million since 2013 constitute of both Emirati citizens and expatriates. The UAE is well-known country that rich in the natural resources specially oil and natural gas. In attempt to maximizing country development, UAE government have invested the oil revenues into the expansion of services sectors as such healthcare, education and infrastructure. Despite of the heavy dependency on the exploitation of the natural resources, UAE government shift the natural resources dependency towards services orientation. As reported by the UAE government (Government.ae, 2018), the total contribution of the travel and tourism sector to the UAE's GDP was AED 159.1 billion (USD 43.3 billion) which is 12.1 per cent of GDP. It is also forecasted to rise by 4.9 per cent per annum to AED 264.5 billion (USD 72 billion) which would be 12.4 per cent of GDP in 2027. Based on Table 1, tourism services became a priority of United Arab Emirates.

Table 1: Travel and Tourism Competitiveness: Contributing Factors. A

\begin{tabular}{|c|c|c|c|c|c|c|c|c|c|}
\hline 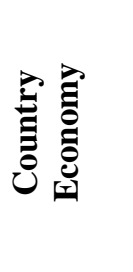 & 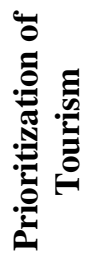 & 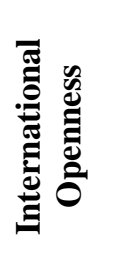 & 晜 & 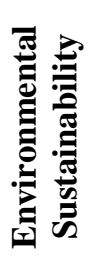 & 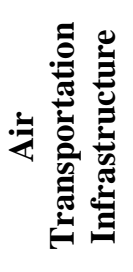 & 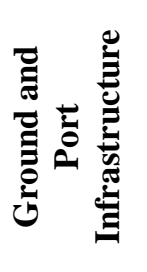 & 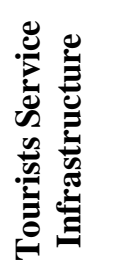 & 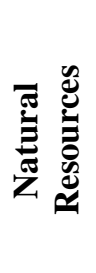 & 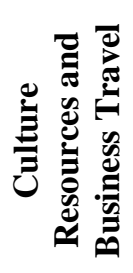 \\
\hline \begin{tabular}{|l} 
UAE \\
\end{tabular} & 4.97 & 2.77 & 4.95 & 4.39 & 5.91 & 5.06 & 5.46 & 2.51 & 1.97 \\
\hline Qatar & 4.89 & 1.93 & 5.33 & 4.32 & 4.17 & 4.79 & 4.81 & 2.12 & 1.48 \\
\hline Bahrain & 4.14 & 2.34 & 5.33 & 3.73 & 3.52 & 5.53 & 4.74 & 1.91 & 1.33 \\
\hline $\begin{array}{l}\text { Saudi } \\
\text { Arabia }\end{array}$ & 4.5 & 1.49 & 5.49 & 3.41 & 3.79 & 3.66 & 4.44 & 2.68 & 1.91 \\
\hline Oman & 4.51 & 2.07 & 5.33 & 4.07 & 2.98 & 4.25 & 4.53 & 2.59 & 1.45 \\
\hline Kuwait & 3.03 & 1.75 & 5.04 & 2.95 & 2.51 & 3.61 & 3.84 & 1.87 & 1.17 \\
\hline
\end{tabular}

Source World Economic Forum (Kukreti, 2017)

\section{TRENDS ON HALAL TOURISM}

Several countries and regions have adopted 'clusters' as a strategy of economic growth, following to the success of Silicon Valley in California. In the Middle- 
East, Dubai has been seen as an example of great success. The UAE has emerged as aninternational country and commercial hub of the Middle-East and South Asia and is one of thefast emerging-markets in the gulf region (Yousaf, S., \& Huaibin, 2014). In the recent years, the UAE government focusing on promoting tourism as the heart of country development since the depletion of oil prices since 2017. Tap with these reformation, UAE government have improvised the hospitality sectors performance by increasing the leisure tourist and ramp up the facilities as such Dubai Parks \& resorts, IMG worlds of Adventure, City walk and leisure and entertainment events at well-known malls namely The Dubai Mall and Mall of the Emirates. The tourism competitive strategy draws by the UAE government embedded in the country vision plan 2030 to empower tourism sectors.

The complete attractiveness of tourism industry at UAE country assemble in the fabulous attraction, a massive cultural heritage, natural diversity as well as developed infrastructure. Due to heavy investment of the government policy and plan, now a day, UAE renowned as the main destination for the Muslim travellers. The Global Muslim Travel Index (GMTI) for 2016 ranked Malaysia first in the world in terms of Muslim travel friendliness. Meanwhile, the UAE moved up one spot to the second place, effectively replacing Turkey (Soltani, 2016). Even though, the total spending on family tourism in the UAE is projected to increase by $4.4 \%$ there are several challenges which are in not about attracting the Muslim tourism, but to engage with Non- Muslim visitors from China and Russia (Soltani, 2016). The UAE country have been acknowledging as an Islamic economic capital of the world and family travel that rest on the halal tourism as the heart of country economic plan. In line with this, Abu Dhabi have granting as the halal travel destination for the visitors and ranked as the primary choices of Muslim shopping destination in the Muslim Travel shopping Index 2015.As reported by World Economic table 2 shows that the UAE positioned in 24 in the global rank and the top in the Gulf Arab region (Kukreti, 2017).

Table 2: Global ranking of UAE in 2015.

\begin{tabular}{|c|c|c|c|}
\hline SI.NO. & Country & Value & Global Rank \\
\hline 1 & UAE & 4.43 & \\
\hline 2 & Qatar & 4.09 & 24 \\
\hline 3 & Bahrain & 3.85 & 43 \\
\hline 4 & Saudi Arabia & 3.8 & 60 \\
\hline 5 & Oman & 3.79 & 65 \\
\hline 6 & Kuwait & 3.26 & 103 \\
\hline
\end{tabular}

Source World Economic Forum (Kukreti, 2017).

The tourism sector plays an important role in enhancing the UAE economic growth (Park, Paris and Park, 2018) and the total contributes to the GDP about 159.1 billion (USD 43.3 billion) which is 12.1 per cent of GDP as reported by (Government.ae, 2018).

Recently, many of developed and developing countries including the UAE have recognized the important of product diversification in the sustainability of tourism industry. One of their initiatives is to develop the

motivation factors of destination towards tourists' satisfaction and loyalty.However, the motivation factors of tourism have been discussed and developed in general without giving a considerable attention to others criteria such as religion, culture and customs which influence the decision of tourists (El-gohary, 2016). This leaves a big challenge to tourism agencies as well as countries in how to satisfy those who are influenced by their culture, religion and lifestyle. More recently, Halal tourism has come to the forefront as a new innovative product targeted Muslims who have their own culture and lifestyle that highly influenced by their religion. The lading tourism countries from both developed and developing countries have taken initiative to develop this industry which led a positive effect on the competitive advantage. For example, Muslims form about $24.1 \%$ of the world population (Waldman and Zeghal, 2009), (Waldman and Zeghal, 2009). According to a report by (Reuters, T., \& Standard, 2015), Halal tourism was worth US\$ 137 billion in 2013 and expected to reach US\$ 181 billion by 2018 .

Despite, the concept of Halal tourism has emerged recently in research and it becomes an important factor in determining the satisfaction of tourists or their loyalty, this concept is still not well known (Wardi, Abror and Trinanda, 2018). There few studies conducted in several countries mostly from Malaysia and Turkey. However, most of them discussed Halal tourism from hotel industry perspective. Therefore, this research aims to come out with new insight about Halal tourism industry from the UAE perspective.

\section{LITERATURE GAPS AND PROBLEM STATEMENT}

The UAE are struggling hard to transform its economy from natural resource based to industrial and services based to mitigate the problem of oil depleting in 2025. As an initiative by the government, the sustainable tourism policy was introduced by the government with aiming to improve the portfolio of tourism revenue. However, the contribution of the tourism to the GDP still less than $12.1 \%$ (Government.ae, 2018). This rises a challenge in how to transform the tourism industry to be more innovative not only in the Arab region, but worldwide as well. The diversity of tourism was one of the government strategy to effectively attract tourists and efficiency gain both tourists satisfaction and return. The Halal tourism was one of the government strategy due to two reasons: first, there are a huge demand from Muslims tourists due to the country location and attractiveness. Second, there are many non-Muslims tourists who are the potential consumers of this vital industry. However, two main problems encountered the policymakers. First, the international competition from Muslims countries such as Malaysia where it jumped to be the first Halal tourism country as shown in Figure 1. This leaves a gap in how to develop an effective model for the development of Halal 
tourism destination that meet tourists' satisfaction and loyalty and transform the UAE to become the highest Halal tourism country in the world.

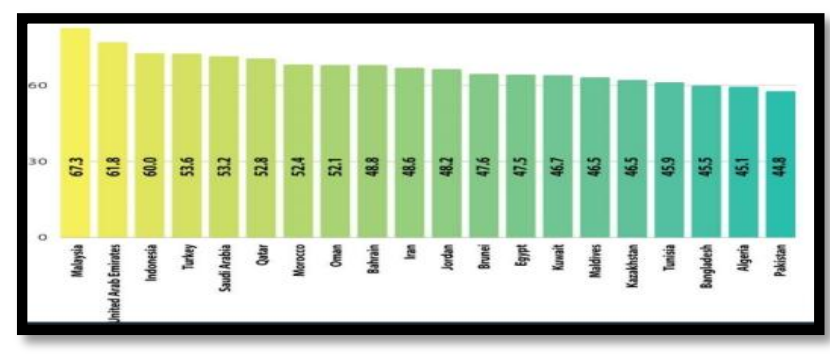

Figure 1: Halal Tourism Report 2019

In addition, the Muslims countries in the Arab region such as Turkey and Egypt and others. Second, the NonMuslims countries that provide Halal tourism products as shown in Figure 2.

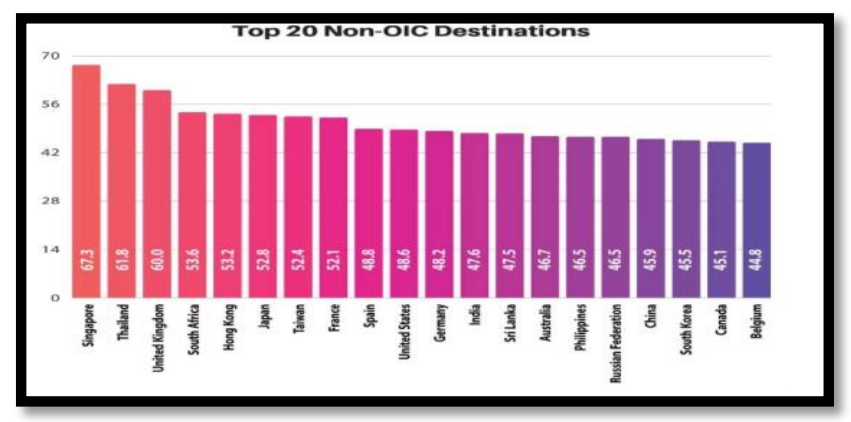

Figure 2: Halal Tourism Report 2019

\section{RESULTS AND DISCUSSION}

To sum up as shown in Figure 3 , it is clear that the UAE has an opportunity to be the first world countries with Halal tourism destination because of several motivation factors such as country tourism infrastructure and facilities (Zaidan, 2016). First, the destination strengths: The UAE has also good experience in managing tourism which adds value to the development of world tourism destination. In addition, the country security as wellas economic stability bring magnificent advantage to the UAE since most of the Middle East countries are suffering of several issues that negatively affect their stability and security. Finally, the UAE location makes in the heart of Middle East where more than $90 \%$ of the population are Muslims and speak Arab makes the country more attractive, especially to those who are looking for a peaceful place. In addition, the country with diversity culture and central of world trade are another strength that give the location such attractiveness.

Second, weakness; Despite the strengths of the UAE as tourism destination (Kukreti, 2017), many weaknesses are surrounding this industry. First, the Halal tourism still lack to consensual definition and the UAE and other countries still lack to a holistic model in defining Halal tourism from the perspective of tourists (Wardi, Abror and Trinanda, 2018). This makes challenge in how to brand Halal tourism that meets tourist satisfaction and loyalty and that also can be used as a model for other countries in the world. The Halal tourism industry lack to innovativeness and it was widely discussed from narrow scope which is Halal and somehow accommodation in Hotel to meet Muslims culture. However, Halal tourism is not only accommodation, but also innovative environment, products and services. This issue may because the development of Halal industry was made based on the government initiative rather than tourists needs. This leaves a big challenge, especially with the rapidly change in customers behaviour and preferences which influence the tourism portfolio and value add to the government GDP (Government.ae, 2018).

Third, industry threats: the UAE as any country is facing a massive competition not only in tourism as whole concept, but also in Halal tourism.For example, the UAE faces competition from Muslims and Arab countries that have great history such as Egypt, Turkey and Saudi Arabia. The UAE faces another challenge in attracting the tourists who are friendly with Halal tourism from the Muslims countries in Asian region, especially from Malaysia. Furthermore, there are many non-Muslims countries are providing and developing Halal tourism destination such as Singapore, Thailand, South Korea and Japan. This put UAE between the waves of global competition (Han et al., 2019). Finally, opportunities: Even though, the UAE is facing a massive competition, precipitated by the frequently touristsbehaviour change and preference, it has a great opportunity to be the world Halal tourism destination. As mentioned early, this country has a great location at the central of market demand and has strong infrastructure with attractive environment.

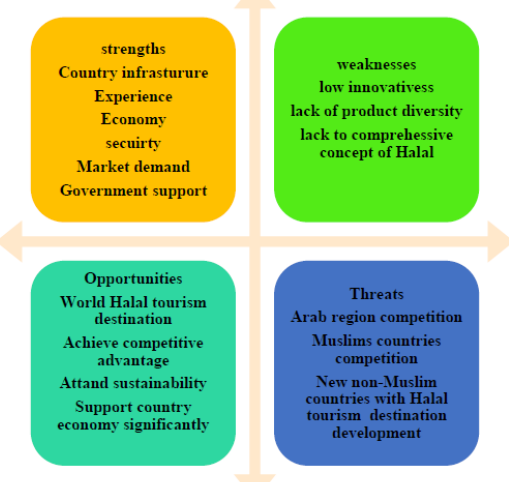

Figure 3: Halal Tourism Analysis in the UAE

Therefore, we argue that, understanding tourists' perspective about the motivation factors that influence them to select the UAE as their Halal tourism destination is the key to develop a holistic model that advances this vital industry. The majority of the past studies addressed the motivation factors towards tourism destination have been conducted either in hotel industry level or the country. Yet, the motivation factors towards Halal tourism destination as country have not received an adequate attention (Wardi, Abror and Trinanda, 2018),

Published By:

Blue Eyes Intelligence Engineering

\& Sciences Publication 
especially in the Arab region. In addition, even though, few recent studies investigated some of the motivation factors that influence Halal tourist destination, most of the have conducted Halal Tourism from Muslims perspective, and ignored non-Muslims tourist who consume Halal tourism products. This leaves a gap in how to attend global consensus about Halal tourism that meet tourists' satisfaction and loyalty regardless their religions. Therefore, an urgent question is raised what are the appropriate motivation model that influence the tourists towards Halal tourism destination in the UAE, which is the central question of this research. The answer of this question has the potential to address the following significant.

\section{CONCLUSION}

In this paper we suggest that addressing the research question will contribute significantly to the body of knowledge and the industry development. First, knowledge and theory contribution: since the concept of Halal tourism still lack to a more understanding, the development of Halal tourism motivation factors from the perspective of the UAE will bring new insight to the body of knowledge in how to define Halal tourism. This will also bring new insight to the theoretical knowledge from push and pull motivation theory in general and from the Halal tourism motivations particularly Second, since most of the study in the literature have conducted Halal Tourism from Muslims perspective, the concept of Halal tourism still narrowed and cannot be globally accepted. Therefore, this research integrates both Muslims and nonMuslims tourists to arrive with an integrative model about the motivation factors of Halal tourism. This will bring new contribution in how to transform Halal tourism to become a global product that accepted by all people. Third, since the UAE government is planning and struggling hard to transform the economy from economy base natural resources and oil to economy base industry and services generally and tourism particularly. However, the contribution of this sector still below $12.1 \%$ due to several reasons and of them innovate tourism services and products to meet tourists' satisfaction. Thus, the outcome of this research will provide a guide to the government in how to increase the portfolio of tourism industry through diversifying its products that meet tourists' satisfaction and loyalty.

\section{REFERENCES}

1. Association of Bhutanese Tour Operators (2018) UNWTO Tourism 2020 Vision Forecast Released. Available at: http://www.abto.org.bt/2010/06/unwto-tourism-2020vision-forecast-released/.

2. Battour, M. and Ismail, M. N. (2016) 'Halal tourism: Concepts, practises, challenges and future', Tourism management perspective. Elsevier Ltd, 19, pp. 150-154. doi: 10.1016/j.tmp.2015.12.008.

3. Cohen, S. A., Prayag, G. and Moital, M. (2014) 'Consumer behaviour in tourism: Concepts, influences and opportunities', Current Issues in Tourism. doi: 10.1080/13683500.2013.850064.
4. Dwyer, L. et al. (2009) 'Destination and enterprise management for a tourism future', Tourism Management. doi: 10.1016/j.tourman.2008.04.002.

5. El-gohary, H. (2016) 'Halal tourism, is it really Halal ?', tourism management perpective. Elsevier Ltd, 19, pp. 124 130. doi: 10.1016/j.tmp.2015.12.013.

6. Garsous, G. et al. (2017) 'Tax Incentives and Job Creation in the Tourism Sector of Brazil's SUDENE Area', World Development. doi: 10.1016/j.worlddev.2017.02.034.

7. Getz, D. and Brown, G. (2006) 'Critical success factors for wine tourism regions: A demand analysis', Tourism Management. doi: 10.1016/j.tourman.2004.08.002.

8. Government.ae (2018) Travel and tourism, Government.ae. Available at: https://government.ae/en/information-andservices/visiting-and-exploring-the-uae/travel-and-tourism.

9. Grissemann, U. S. and Stokburger-Sauer, N. E. (2012) 'Customer co-creation of travel services: The role of company support and customer satisfaction with the cocreation performance', Tourism Management. doi: 10.1016/j.tourman.2012.02.002.

10. Hafeez, K. et al. (2016) 'The role of place branding and image in the development of sectoral clusters: The case of Dubai', Journal of Brand Management, 23(4), pp. 383402. doi: 10.1057/bm.2016.18.

11. Han, H. et al. (2019) 'Exploring halal-friendly destination attributes in South Korea: Perceptions and behaviors of Muslim travelers toward a non-Muslim destination', Tourism Management. Elsevier, 71, pp. 151-164. doi: 10.1016/j.tourman.2018.10.010.

12. Holloway, J. C. and Humphreys, C. (2017) The Business of Tourism. Edited by 10th ed. Pearson Higher Ed,.

13. Jönsson, C. and Devonish, D. (2008) 'Does nationality, gender, and age affect travel motivation? A case of visitors to the Caribbean Island of Barbados', Journal of Travel and Tourism Marketing, 25(3-4). doi: 10.1080/10548400802508499.

14. Khuong, M. N. and Ha, H. T. T. (2014) 'The Influences of Push and Pull Factors on the International Leisure Tourists' Return Intention to Ho Chi Minh City, Vietnam - A Mediation Analysis of Destination Satisfaction', International Journal of Trade, Economics and Finance. doi: 10.7763/IJTEF.2014.V5.421.

15. Kukreti, M. (2017) 'Omani Journal of Applied Sciences ( OJAS ) Annual Refereed Scientific Journal PATRON H E . Dr . Abdullah Mohammed Al Sarmi The Undersecretary of the Ministry of Higher Education Dr . Abdullah Al Shibli EDITOR MANAGER Dr . Zubeir Izaruku Dafalla', Omani Journal of Applied Sciences, 6(1), pp. 1-110.

16. Lubbe, B. (2005) Tourism Management in Southern Africa. 2ed editio. South Africa: Pearson Education Limited.

17. Mai, T. Van and Bosch, O. J. H. (2010) 'Systems thinking approach as a unique tool for sustainable tourism development: a case study in the cat ba biosphere reserve of vietnam', Proceedings of the 54th Annual Meeting of the ISSS.

18. Park, D. K., Paris, C. M. and Park, D. K. (2018) 'Soft power and place branding in the United Arab Emirates : examples of the tourism and film industries Donya Saberi * Belisa Marochi', Int. J. Diplomacy and Economy, 4(1), pp. 44-58.

19. Perks, S. and Ferreira, D. (2017) 'Needs-driven based marketing strategies to attract South African outbound tourists', African Journal of Hospitality, Tourism and Leisure, 6(4), pp. 1-21. 
20. Qian, J., Law, R. and Wei, J. (2018) 'Effect of cultural distance on tourism: A study of pleasure visitors in Hong Kong', Journal of Quality Assurance in Hospitality and Tourism. doi: 10.1080/1528008X.2017.1410079.

21. Razzaq, S., Hall, C. M. and Prayag, G. (2016) 'The capacity of New Zealand to accommodate the halal tourism market - Or not', Tourism Management Perspectives. doi: 10.1016/j.tmp.2016.01.008.

22. Reuters, T., \& Standard, D. (2015). (2015) State of the Global Islamic Economy Report 2013.

23. Scheyvens, R. and Russell, M. (2012) 'Tourism and poverty alleviation in Fiji: Comparing the impacts of small- and large-scale tourism enterprises', Journal of Sustainable Tourism. doi: 10.1080/09669582.2011.629049.

24. Seyidov, J. and Adomaitienè, R. (2016) 'FACTORS INFLUENCING LOCAL TOURISTS' DECISIONMAKING ON CHOOSING A DESTINATION: A CASE OF AZERBAIJAN', Ekonomika. doi: 10.3748/wjg.v20.i34.11962.

25. Shafaei, F. and Mohamed, B. (2015) 'Malaysia ' s branding as an Islamic tourism hub : An assessment', 1(1), pp. $97-106$.

26. Soltani, S. (2016) Search Spending On Halal Tourism In UAE To Increase By 4.4\%, Hotel News. Available at: http://www.hotelnewsme.com/news/spending-halaltourism-uae-increase-4-4/.

27. Waldman, M. R. and Zeghal, M. (2009) Islamic world, Britannica. Available

at: https://www.britannica.com/topic/Islamic-world.

28. Wardi, Y., Abror, A. and Trinanda, O. (2018) 'Halal tourism: antecedent of tourist's satisfaction and word of mouth (WOM)', Asia Pacific Journal of Tourism Research, 23(5), pp. 463-472. doi: 10.1080/10941665.2018.1466816.

29. Yousaf, S., \& Huaibin, L. (2014) 'Branding Pakistan as a "Sufi" country: the role of religion in developing a nation's brand.', Journal of Place Management and Development, 7(1), pp. 90-104.

30. Zaidan, E. (2016) 'The impact of cultural distance on local residents perception of tourism development: The case of Dubai in UAE', Tourism, 64(1), pp. 109-126. 